\title{
The Politics of Global Disorder
}

\author{
Jeffrey C. Isaac
}

$\mid$ began drafting this Introduction the day after the December 2 mass murder in San Bernadino, CA committed by two suspected ISIS sympathizers, and within weeks of the November 15 coordinated mass murders in Paris committed by ISIS sympathizers. A taste of the violence that engulfs the Middle East on a daily basis was thus visited upon the "homelands" of the United States and France. The immediate response in both countries was a call for greater "domestic security" (in post-9/11 parlance, "homeland security") and a determination to upgrade the air war against ISIS in the territories of Syria and Iraq now occupied by "the Islamic State."

ISIS ("The Islamic State in Iraq and Syria") or ISIL ("The Islamic State of Iraq and the Levant") or Daesh (a perjorative Arabic acronym?) - by any of these names, a new entity, barely one year old, now claims sovereignty over a substantial territory crossing the boundaries of longestablished Middle Eastern states, inciting and organizing violent terror attacks throughout the world in the name of its "caliphate." ISIS emerged out of the civil wars in Iraq and Libya that followed the U.S.-led toppling of the regimes of Saddam Hussein and Moammar Qadaffi, and it has found fertile soil in Syria, where the violent repression of the Assad regime set off a vicious civil war. This Middle East inferno has brought to the fore a wide range of pressing issues. The murder and displacement of millions in Syria, Iraq, and Libya has caused a refugee crisis of epic proportions. The aerial attacks being conducted by the United States, France, Great Britain, and Russia raise questions about the pragmatic and moral limits of aerial bombing campaigns and remote-controlled drone strikes —questions accentuated by the October 2015 U.S. bombing of a Doctors Without Borders hospital in Kunduz, Afghanistan that killed 30 and injured many more, all civilians. The haphazard and uncoordinated response of many intervening states—epitomized by the Turkish downing of a Russian plane over (disputed) Turkish air space-highlights the lack of any meaningful form of global governance capable of dealing with the issues in play.

The current crisis poses intellectual and also practical challenges, as Marc Lynch notes in his "Praxis" essay, "Political Science in Real Time: Engaging the Middle East Policy Public." This issue of Perspectives contains a wide range of articles, essays, and reviews that shed light on various aspects of this situation.

Our lead article, Wendy Pearlman's "Narratives of Fear in Syria," presents a "thick description" of ordinary Syrian experiences of fear based on interviews with 200 Syrian refugees. Pearlman distinguishes between four types of fear-silencing fear, surmounted fear, semi-normalized fear, and nebulous fear-and traces the way that fear is articulated by her respondents in connection with the evolving political situation confronting the Assad regime and the Syrian population. As she writes: "Before the uprising, fear was a pillar of the state's coercive authority. Popular demonstrations generated a new experience of fear as a personal barrier to be surmounted. As rebellion militarized into war, fear became a semi-normalized way of life. Finally, protracted violence has produced nebulous fears of an uncertain future." Pearlman insists that the lived experience of fear is an important dimension of politics that ethnographic accounts can capture in a way that more institutional accounts cannot. While she acknowledges the limits of such ethnographies, she argues that: "Study of these testimonials aids understanding of Syria and other cases of destabilized authoritarianism by elucidating lived experiences obscured during a repressive past, providing a fresh window into the construction and evolution of national identity, and demonstrating how the act of narration is an exercise in meaning making within a revolution and itself a revolutionary practice."

Holger Albrecht and Dorothy Ohl's "Exit, Resistance, Loyalty: Military Behavior During Unrest in Authoritarian Regimes" analyzes the central role that military actors have played during the Arab uprisings of 2011 and their aftermath. Like Pearlman, Albrecht and Ohl also draw on extensive fieldwork. They also develop a principal-agent model based on the insight that "disaggregating 'the' military and parsing the interests of different agents in that apparatus is crucial for explaining exit, resistance, and loyalty patterns at the start of an uprising and as it continues." They then apply this model to explain "varying degrees and types of military cohesion in three Arab Spring cases: Bahrain, Yemen, and Syria," and conclude: "During Syria's unrest, the military saw most commanders remain loyal while subordinates across a range army units defected, in the vast majority of cases doing so 
individually. This led to a pattern of horizontal defections. When similar unrest broke out in Yemen, we witnessed corporate insubordination of individual units: certain military commanders and subordinates within the same unit either defected or remained loyal, resulting in a pattern of vertical defection. Finally, Bahrain witnessed dual loyalty of both commanders and soldiers." Albrecht and Ohl argue that these varying dynamics engender different "conflict trajectories" during the rebellion and post-rebellion phases, and suggest that their account helps make sense of both the Syrian civil war and the shocking and precipitous collapse of the Iraqi army in the face of ISIL since January 2014. (Their account is usefully read alongside our Critical Dialogue between Scott Straus, author of Making and Unmaking Nations: War, Leadership, and Genocide in Modern Africa, and Paul Staniland, author of Networks of Rebellion: Explaining Insurgent Cohesion and Collapse).

Charli Carpenter's "Rethinking the Political-/Science/Fiction Nexus: Global Policy and the Campaign to Stop Killer Robots" is both a terrific overview of the burgeoning literature on science fiction and international relations and "an evidence-based exploration of the relationship between science-fiction narratives and global public policy in an important emerging political arena: norm-building efforts around the prohibition of fully autonomous weapons." Carpenter proceeds from the observation that "Science fiction and fantasy are increasingly invoked by policy elites in service of arguments about the real world," and are also invoked by movement activists seeking to promote limits on the new automated technologies of destruction. Carpenter's piece is a self-described "plausibility probe" of the ways that science fiction tropes are mobilized in this domain. As she concludes: "My analysis suggests that while transnational activists have not necessarily been causally influenced by killer-robot fiction in the way commentators sometimes assume (in fact rather the reverse), such cultural memes certainly do help constitute the socio-political context in which campaigners must navigate to be effective. In particular, my interview data points to an effect overlooked in earlier literature: the role of science-fiction/fantasy discourse as a social lubricant among divergent and often highly contested policy communities. I also argue that under some circumstances, science fiction, far from 'enabling' policy as much literature assumes, can instead exert a 'disabling' effect on global norm development. Ultimately, this case demonstrates the value of treating assumptions about popular culture's relationship to politics as hypotheses to explore, rather than interpretations to assert." Carpenter's article is at once a contribution to constructivist theorizing in IR scholarship, serious discussion of multi-method research, and the analysis of the new cultural environment in which warfare is increasingly automated, remote-controlled, "surgical," and at the same time extremely destructive (it is thus usefully read alongside Matthew Evangelista's review essay on drone warfare, "Is War Too Easy?").
With Mara Pillinger, Michael Barnett, and Ian Hurd's "How to Get Away with Cholera: The UN, Haiti, and International Law," we turn to the limits of international law and of legalism more generally. If our first three articles deal, in different ways, with the rapid and lethal circulation of violence, this piece proceeds from the viral spread of disease itself. As the authors write: "The legalization of world politics is often celebrated for reducing impunity for those who contribute to humanitarian crises. This may sometimes be true but its opposite is also true. In 2010 United Nations peacekeepers unwittingly brought cholera to Haiti and sparked an epidemic. Nearly a million people were made sick and 8,500 died. The episode has become an international political crisis for the UN and as activists seek legal accountability they have found themselves blocked by the structures of public international law. Rather than reduce impunity, international law in this case has insulated the UN from accountability for the harms it caused. The UN is empowered, and the cholera victims disempowered, by legalization." Pillinger, Barnett, and Hurd present a powerful account of the tribulations of Haiti, the Western hemisphere's poorest country, in the face of "natural" and "man-made" disasters. They also trace the complex relationships between political elites, domestic and international civil society actors, and the institutions of international law and global governance. These broad themes are also addressed in Sarah Stroup and Wendy Wong's review essay, "The Agency and Authority of International NGOs," and they are also considered in two of our Critical Dialogues: between Amanda Murdie, author of Help or Harm: The Human Security Effects of International NGOs and Carew Boulding, author of NGOs, Political Protest, and Civil Society; and between Jennifer Mitzen, author of Power in Concert: The Nineteenth Century Origins of Global Governance, and Barry Buzan and George Lawson, authors of The Global Transformation History, Modernity and the Making of International Relations. And the more general limits of global governance are also discussed in our Critical Dialogue between Joan Cocks, author of On Sovereignty and Other Political Delusions (Theory for a Global Age) and Thomas Pavel, author of Divided Sovereignty: International Institutions and the Limits of State Authority.

With Robert Falkner's “A Minilateral Solution for Global Climate Change? On Bargaining Efficiency, Club Benefits, and International Legitimacy," we turn to what is perhaps the biggest global governance challenge facing humanity-global climate change. As Falkner writes: "Climate change is not the only area of global concern in which established multilateral processes have failed to produce the required level of international cooperation. Political scientists warn of increasing gridlock in global governance across a number of international policy arenas, from financial regulation to nuclear non-proliferation and public health. In the environmental field, evidence is 
mounting that humanity is unable to provide adequate policy responses to resource scarcity, degradation of ecosystems, and the reduction of the planet's ability to absorb waste and pollution. The magnitude of the global challenge is illustrated by what scientists have recently coined the advent of the 'Anthropocene,' a geological era in which human activities rival global geophysical forces in shaping the planet. As the Anthropocene unfolds and business-as-usual trends are pushing us against global planetary boundaries, the limitations of conventional top-down approaches in international governance are becoming increasingly apparent." Falkner surveys a range of arguments for more "minilateralist" approaches, subjecting each to careful consideration, and concluding that while these approaches are "unlikely to overcome the structural barriers to a comprehensive and ambitious international climate agreement ... [they] can enhance political dialogue in the context of multilateral negotiations and can provide a more conducive environment for great power bargaining. They can create club benefits that strengthen mitigation strategies and help reduce the dangers of free-riding for so-called coalitions of the willing. And they can help re-legitimate the global climate regime against the background of profound power shifts that have slowed down progress in the multilateral negotiations." The prospects for the a reform of the global climate regime are also discussed in two Critical Dialogues: between Hayley Stevenson and John Dryzek, authors of Democratizing Global Climate Governance, and Frank Biermann, author of Democratizing Global Climate Governance; and between John M. Meyer, author of Engaging the Everyday: Environmental Social Criticism and the Resonance Dilemma and Walter F. Baber and Robert V. Barlett, authors of Consensus and Global Environmental Governance: Deliberative Democracy in Nature's Regime.

Loubna El Amine's "Beyond East and West: Reorienting Political Theory Through the Prism of Modernity" is a work of normative political theory that speaks directly to the issues noted above. El Amine proceeds via a critical engagement with "comparative political theory," an increasingly important genre of political theory which has sought to displace the Eurocentrism of much conventional historical and normative political theory. The principal advocates of "comparative political theory" argue that it is impossible to understand either the evolution or current dynamics of modern states and modern world politics without attending to the importance of non-Western sources, traditions, and experiences. El Amine acknowledges the advances brought by this approach, but argues that it "does not offer the resources to deal with global convergence as embodied in the phenomenon of modernity. I focus on the emergence of the sovereign state in the modern period and argue that the universal acceptance of the state form creates a globally-shared institutional condition. This condition, in turn, necessitates a shared normative and conceptual apparatus centered on ideals like constitutionalism, rights, and democracy. Two implications follow from my argument. First, we should reconceptualize the history of political thought such that we move from an East/West division to a modern/pre-modern division. Second, alternatives to the dominant ("Western") model are not real alternatives unless they transcend the sovereign state itself, charting a new course of multilayered local, regional, and global political arrangements."

El Amine's argument centers on a critique of the valorization of Confucianism by many commentators on Chinese politics. She notes, for example, that the central slogan of the 2014 Hong Kong protest movement which became known as "Occupy Central," "When dictatorship becomes a reality, revolution is a duty,' was not an echo of the Confucian tradition, but rather traceable to Victor Hugo." And she argues that: "modernity, understood as a set of material conditions coalescing around the modern state and the international order that sustains it, is not only a useful concept, but that it is also necessary, precisely to make sense of the protestors' mottos cited above. In short, given that China, as well as Tunisia, Egypt, Yemen, and Syria, are centralized, bureaucratized, industrialized, and sovereign states, just like South Africa, Thailand, and Greece, it makes perfect sense that the slogans of their protestors be similar. The slogans do not signal the final triumph of Western values. What they symbolize is a common discourse of resistance to political authority that stems from facing common challenges brought about by shared material conditions." (Sidney Tarrow's War, States, and Contention is a major work, at the intersection of comparative politics and international relations, that raises similar questions about these institutional conditions and dynamics of contention, and our symposium features comments by Elisabeth Prugl, Daniel Slater, and Richard Vallely.)

Our symposium on Daniel Bell's book The China Model: Political Meritocracy and the Limits of Democracy addresses precisely this theme, and our commentatorsBaogang He, Victoria Hui, Leigh Jenco, Andrew Nathan, Lynette Ong, Thomas Pangle, and Joseph Wong-offer a range of perspectives on the extent to which China represents a distinctively efficient and meritocratic "model of governance" that is neither liberal democratic nor authoritarian. Many of the commentators echo El Amine's basic point that "common challenges brought about by shared material conditions" necessitate "a shared normative and conceptual apparatus centered on ideals like constitutionalism, rights, and democracy." China's "Asian model" is not simply the system governing the world's largest nation-state; it is also the formula of rule favored by one of the world's most important geopolitical powers. And so what is at stake in this 
discussion are fundamental questions of both domestic rule and global governance.

Finally, we are pleased to publish Rodney Hero's 2015 APSA Presidential Address, "American Politics and Political Science in an Era of Growing Racial Diversity and Economic Disparity." While the current issue of Perspectives deals mainly with global questions, Hero's address deals with a theme we have featured in many issues of our journal-the complex intersections of diversity, disparity, and inequality in the United States. While Hero is primarily concerned with the responsibilities of American political scientists to address the challenges of American politics, in a broader sense his address sounds a theme that has been central to this journal from the start-that political science is in the world and of the world, and much of its value centers on its ability to shed light on problems of human living together in our common and very much fractured world.

\section{A Statement on the Importance of Scholarly Sharing and Recognition}

Perspectives on Politics has long been committed to promoting scholarly sharing, among political scientists and between political scientists and other reading publics, that is serious, rigorous, relevant, honest and intellectually fair.

In light of the rhetoric of intellectual probity surrounding the controversy over the DA-RT ("Data Access and Research Transparency") initiative, we think it important to issue a statement publicly reiterating one of our journal's long-standing practices and also announcing a new policy regarding citation practices.

\section{(1) Perspectives has long been committed to the highest standards of general research transparency.}

Perspectives is a scholarly journal of political science fully committed to double-blind peer review of all research articles and to honest and open sharing of ideas and evidence. We regard such commitments as essential to the publicity and intellectual care at the heart of all serious scholarly inquiry and publication. Our policies have reflected these commitments from the start of our editorship.

Since 2009 we have thus shared versions of the letter at bottom with all authors of articles we are publishing. The letter encourages authors to make their evidentiary sources, including data, accessible, and invites them to take advantage of resources provided by the journal and Cambridge University Press (who hosts supplemental material at permanent links) to prepare these sources in a manner that seems reasonable given their work and their personal convictions as authors and valued colleagues.

This policy has been voluntary and it will remain voluntary. At the same time, we work very closely with authors in the development of their work, and in recent years this sharing has been strongly encouraged as part of a more general conversation about how to publish the best work possible. A number of articles in our current issue offer methodological appendices that exemplify our journal's approach to these issues.

(2) Perspectives is fully committed to the ethical value of inclusivity and appropriate scholarly recognition of the work of others.

Two years ago, in response to widespread discussion of the issue within the profession, our editorial board initiated a serious discussion of the problem of gender bias in citation practices and other forms of bias as well. At our 2015 annual board meeting in San Francisco, the board voted unanimously to adopt changes in the instructions we send to all book and manuscript reviewers that underscore the importance of citing all relevant sources.

We have thus incorporated the following language into all reviewer letters:

"In considering these questions, the work's treatment of relevant literatures and authors is particularly germane to your evaluation. If you have concerns about citation bias, regarding gender, people of color, or other under-represented scholarly communities, these would also be worth noting. Obviously, your evaluation will be based largely on your reading of the work as a scholarly expert. But please keep in mind that Perspectives on Politics is a distinctive kind of political science journal, and seeks to promote research that is integrative and that reaches broadly within political science."

Both of these measures serve the same purpose: promoting forms of research practice and scholarly discourse that enact proper regard for the intersubjective character of scientific practice. We believe strongly that all scholars ought to pay attention to and acknowledge the work of others relevant to their own work, and that all scholars ought to present their work in a way that makes it accessible to critical scrutiny by others in the field.

Jeffrey C. Isaac, Editor in Chief James Moskowitz, Managing Editor 


\section{Letter on Supplemental Materials and Research Transparency}

Dear Contributor,

On the first page of articles (and presidential addresses!), Perspectives on Politics includes a note to readers regarding the availability of supplemental materials. Online materials may include additional tables, graphs, and extended commentary. We encourage authors to supply appropriate materials for the purposes of transparency and/or replication. Therefore, as we approach the proofs/copy editing stage for each accepted article, we ask that you supply our offices with some information about the materials you deem necessary to fulfill this important scholarly responsibility.

Authors of articles in this journal that rely on quantitative data are encouraged to provide-for storage in a Cambridge University Press-provided public archive - the information necessary to replicate their numerical results. The information deposited should include items such as original data, specialized computer programs, lists of computer program recodes, extracts of existing data files, and most important, an explanatory file that describes what is included and explains how to re-produce the exact numerical results in the published work.

Authors of works relying upon qualitative data are encouraged (but not required) to submit comparable materials that would facilitate replication where feasible, and that would allow readers to clearly evaluate the evidentiary basis of arguments for interpretive research in which "replication" is not an appropriate standard. In many cases article endnotes properly citing all sources and references are sufficient.

Statements explaining the inappropriateness of sharing data for a specific work (or of indeterminate periods of embargo of the data or portions of it) can fulfill the journal expectation. If necessary, peer reviewers can be asked to assess this statement as part of the general evaluative process, and to advise the editor accordingly. In almost all cases of limited access, some excerpt or sub-sample of data can be provided in the interim.

As always, authors are advised to remove information from their data sets that must remain confidential, such as the names of survey respondents. Also as always, we affirm our commitment to the autonomy of our authors. Your research and writing is your own, and you are the best judge of the kinds of supplementary materials that are best suited to your style of research and writing.

In establishing these expectations, our goal is to facilitate the kind of publicity that is at the heart of scholarly communication.

To submit files, or documents, please reply with attachments to this email...

An example of how this appears in the pages of Perspectives is attached. You can also see examples online at CJO:

Amaney A. Jamal, Robert O. Keohane, David Romney, and Dustin Tingley. 2015. "Anti-Americanism and Anti-Interventionism in Arabic Twitter Discourses." Perspectives on Politics 13(1): 55-73.

DOI: http://dx.doi.org/10.1017/S1537592714003132

Lindsay J. Benstead, Amaney A. Jamal, and Ellen Lust. 2015. "Is It Gender, Religiosity or Both? A Role Congruity Theory of Candidate Electability in Transitional Tunisia." Perspectives on Politics 13(1): 74-94.

DOI: http://dx.doi.org/10.1017/S1537592714003144

Understandably, the actual files may take some time to prepare. These could follow any time after your response to this letter-as long as they arrive before the issue is sent to the compositor.

Best wishes, James Moskowitz Managing Editor 


\section{Statement of Mission and Procedures}

Perspectives on Politics seeks to provide a space for broad and synthetic discussion within the political science profession and between the profession and the broader scholarly and reading publics. Such discussion necessarily draws on and contributes to the scholarship published in the more specialized journals that dominate our discipline. At the same time, Perspectives seeks to promote a complementary form of broad public discussion and synergistic understanding within the profession that isessential toadvancing scholarship and promoting academic community.

Perspectives seeks to nurture a political science public sphere, publicizing important scholarly topics, ideas, and innovations, linking scholarly authors and readers, and promoting broad reflexive discussion among political scientists about the work that we do and why this work matters.

Perspectives publishes work in a number of formats that mirror the ways that political scientists actually write:

Research articles: As a top-tier journal of political science, Perspectives accepts scholarly research article submissions and publishes the very best submissions that make it through our double-blind system of peer review and revision. The only thing that differentiates Perspectives research articles from other peer-reviewed articles at top journals is that we focus our attention only on work that in some way bridges subfield and methodological divides, and tries to address a broad readership of political scientists about matters of consequence. This typically means that the excellent articles we publish have been extensively revised in sustained dialogue with the editor-me-to address not simply questions of scholarship but questions of intellectual breadth and readability.

"Reflections" are more reflexive, provocative, or programmatic essays that address important political science questions in interesting ways but are not necessarily as systematic and focused as research articles. These essays often originate as research article submissions, though sometimes they derive from proposals developed in consultation with the editor in chief. Unlike research articles, these essays are not evaluated according to a strict, doubleblind peer review process. But they are typically vetted informally with editorial board members or other colleagues, and they are always subjected to critical assessment and careful line-editing by the editor and editorial staff.

Scholarly symposia, critical book dialogues, book review essays, and conventional book reviews are developed and commissioned by the editor in chief, based on authorial queries and ideas, editorial board suggestions, and staff conversations.

Everything published in Perspectives is carefully vetted and edited. Given our distinctive mission, we work hard to use our range of formats to organize interesting conversations about important issues and events, and to call attention to certain broad themes beyond our profession's normal subfield categories.

For further details on writing formats and submission guidelines, see our website at http://www.apsanet.org/ perspectives/ 